\title{
8.15 Деякі питання навчання фізики в інтегрованому курсі 3 природничих наук
}

Природничі науки змінюють наше життя і є життєво важливими для сталого розвитку не лише для нашої країни, а в цілому для світу. Саме тому в багатьох країнах світу пильна увага приділяється вдосконаленню системи природничої освіти, що полягає у розробленні їі варіативності, різнорівневості вимог до навчальних результатів учнів, урізноманітненні форм і методів організації навчальної діяльності. Така диференціація навчання найповніше реалізується у старшій профільній школі, де вивчення кожного 3 природничих предметів передбачено за двома рівнями (рівень стандарту і профільний рівень), а також у вигляді інтегрованого курсу «Природничі науки».

Навчання інтегрованого курсу 3 природничих наук пов'язане iз систематизацією та узагальненням знань про явища реального світу.

Концепцією структури та змістом загальної освіти у школі є: особистісна орієнтація змісту освіти; гуманізація та гуманітаризація, що забезпечують фізичну, інтелектуальну, духовно-моральну освіту учнів; фундаментальність змісту освіти, що забезпечує універсальність здобутих знань; пріоритетність збереження здоров'я учнів, у тому числі за рахунок розвантаження навчального матеріалу; забезпечення практичної орієнтації загальної середньої освіти шляхом раціонального поєднання продуктивної та репродуктивної діяльності учнів; забезпечення цілісності уявлення учнів про світ шляхом інтеграції змісту освіти.

Фізика, поруч із розв'язанням цих завдань, формує творчі здібності учнів, ïx світогляд i переконання, тобто сприяє розвитку та вихованню високоморальної особистості. Ця мета навчання може бути досягнута тільки тоді, коли в процесі навчання фізики учень отримує певні знання та вміння їх набувати.

Систематичний курс фізики, як фундамент природничих наук, формує, уточнює та розвиває знання, отримані в курсі вивчення географії, біології та 
природознавства. Створюється уявлення про цілісність всесвіту, взаємозв'язки та взаємодії його частин, матеріальних та енергетичних перетвореннях у часі та просторі, про різноманітні природні зв'язки, що важливо для інтелектуального розвитку учнів.

Фізика - основа техніки, тому широко використовується для досліджень у біології, географії, історії та екології. У наші дні радіо, телебачення, популярна література активно знайомлять із новими досягненнями науки та техніки. Цю інформацію необхідно використовувати, узагальнювати, застосовувати на уроках та позакласних заняттях і заходах. Цілий ряд фізичних відомостей отримують учні під час уроків біології, географії, природознавства, хімії, екології, історії, а також за рахунок власних спостережень за рослинним світом, природними умовами. Це дає можливість урізноманітнити уроки, зробити їх захоплюючими, цікавими, незабутніми. Активізувати діяльність учнів, розвивати в них творчі можливості, логічне мислення дозволяють завдання, що мають зв'язок з дисциплінами природничого, історичного та гуманітарного циклу.

Міжпредметні зв'язки сприяють формуванню в учнів цілісного ставлення до явищ природи, допомагають їм використовувати знання щодо різних предметів. Адже світ, що нас оточує, цікавить школярів, спонукає їх відповідати на питання, які перед ними ставить життя. Тому введення у навчальний процес ілюстративних відомостей з історії, екології, географії, біології дає можливість вчителю під час навчання фізики більше пов'язати предмет із важливими аспектами життя природи, з діяльністю людини, з історією.

Застосування прикладів та завдань, практичних та дослідницьких робіт 3 елементами історії, географії, біології, екології на уроках та у позаурочний час допоможе кращому засвоєнню навчального матеріалу. Залучення цього матеріалу служить розвитку у дітей творчих здібностей, вміння спостерігати, формує вміння роботи $з$ додатковою літературою, формує вміння застосовувати знання з пояснення явищ природи у житті. 
Поява природи взаємно пов'язані. Цей взаємозв'язок необхідно розкривати перед учнями щодо всіх природничих дисциплін.

Велику роль у формуванні цілісної картини світу під час уроків фізики грає складання і розв'язання задач. Ці задачі повинні задовольняти певним вимогам: вони повинні бути пов'язані з темою, що вивчається, і сприяти більш міцному і глибокому засвоєнню фізичних закономірностей, повинні навчити практичному застосуванню цих закономірностей в біології, хімії, географії, історії, екології. Дуже корисна робота 3 додатковою та довідковою літературою, на основі якої школярі самостійно можуть складати завдання та повідомлення до уроку. Звичайно, доцільніше викладати цей матеріал з використанням комп'ютерних технологій, відеотехніки, плакатів та ілюстрацій, географічних та історичних карт, таблиць та наочних посібників.

Так щодо теми «Капілярні явища» можна показати уривки відеофільму «Кровоносна система», «Будова кореня». Під час вивчення теми «Око - оптична система» можна показати плакат «Зір у тваринному світі» тощо. Найголовніше це не перевантажити урок наочними посібниками, щоб він не втратив фізичну сутність.

Для багатьох учнів ці приклади можуть стати засобом прищеплення інтересу до фізики. Залучення фрагментів з елементами біології, хімії, географії, історії, екології покликане формувати в учнів любов до природи, збагачувати образне мислення, розвивати фантазію, що є чинником успішного засвоєння навчального предмета. Вирішення фізичних завдань допоможе пробудити у школярів інтерес до предмета, розширити їх знання та кругозір, краще зрозуміти фізику.

Створення поглядів на основні поняття навколишнього світу починається з 5 класу. Для формування уявлень про дискретну будову речовини на початку вводиться поняття «маса» як властивість тіла. На наступному етапі, в 7 класі, вводиться поняття речовини, яке складається з величезної кількості часток, що хаотично рухаються, що підтверджується експериментально дослідами з дифузії. Цей процес розглядається в біології стосовно функціонування живих організмів. 
Подальший розвиток уявлення про дискретну будову речовини учні отримують у темах електромагнітні явища та будова речовини.

Вся система знань про дискретну будову тіл і речовин дозволяе і в курсі природничих наук зробити важливий у методологічному відношенні висновок про пізнаваність та невичерпність матерії.

Важливим етапом у пізнанні учням навколишнього світу $є$ введення поняття про взаємодію матеріальних об'єктів, який починається 3 простого експерименту зі свинцевими циліндрами і триває при вивченні теми «Сили природи».

Початкові відомості про силу учні отримують із повсякденного досвіду. Вони зазвичай пов'язують ії з м'язовим зусиллям. Тому в курсі природничих наук дається наукове визначення сили як характеристики дії одного тіла на інше. У основній школі учні повинні засвоїти, що 3 кожної сили вказується точка докладання, напрями і модуль. Крім того, вводиться позначення сили та одиниця виміру. У результаті складається уявлення про цілісність навколишнього світу, про взаємодію тіл між собою, розглядаються прояви різних сил у природі, техніці, побуті.

Формування ключового питання існування пов'язане 3 поняттям «Енергії». Починається воно з введення поняття роботи як міри вимірювання енергії при трансформації стану тіла і процесом, що відбувається на землі. 3 цієї точки зору можна говорити про екологічну безпеку зміни форми поверхні суші, втрати родючих земель, заболочування тощо.

При вивченні теми «Світлові явища» надається можливість обговорити питання про перетворення сонячної енергії на хімічну при фотографуванні. Закони, що вивчаються в цій темі, можуть допомогти пояснити: забруднення атмосфери при згорянні палива; вплив випромінювань (ультрафіолетового та інфрачервоного) на життєдіяльність людини, тварин, рослин; зміна світлового режиму морів та океанів через забруднення поверхні води нафтопродуктами. У курсі фізики вивчення цієї теми дозволяє учням отримати такі знання (затребувані й у курсі природознавства): різні джерела світла; закон 
прямолінійного поширення світла та його прояви; закон відображення світла та його застосування; прояв та використання явища заломлення світла у природі, техніці, побуті; розкладання білого світла на спектр; веселка; будова та функції ока людини; причини виникнення дефектів зору; особливості зору комах, птахів, звірів, тощо.

У процесі вивчення теми «Звукові явища» учні переконуються, що звук джерело різноманітної інформації.

Фізика, як наука, робить особливий внесок у вирішення загальних завдань освіти та виховання особистості. У цьому курсі учні отримують початкові відомості про електрику та магнетизм, 3 наступним переходом до електромагнітних явищ. До них відносяться і світлові явища, знання законів яких важливе не лише для вивчення природничих наук, а й для художників, кінематографістів та інших людей творчих професій. Таким чином, саме при вивченні фізики створюється цілісне уявлення про світ, оскільки вся система знань про явища природи, властивості простору та часу, речовину та поле формує науковий світогляд. Інтеграція природничих знань дозволила б:

- сформувати уявлення школярів про цілісну картину світу з його єдністю та різноманіттям властивостей живої та неживої природи

- показати єдність законів природи, застосування законів і теорії фізики до різних об'єктів (від елементарних частинок до далеких галактик)

- розглянути різні рівні організації речовини (мікроскопічний, макроскопічний)

• розглянути кругообіг речовин та перетворення енергії

- розглянути людину як фізичний об'єкт, людину як складну фізичну систему, людину як суб'єкт пізнання

- показати вплив на живий організм довкілля (теплове, світлове, шумове, електромагнітне, радіаційне).

Тому наукова картина світу повинна створюватися у школярів за рахунок інтеграції наукового пізнання всіх наук складових природничого циклу. 
Методика використання текстів, пов'язаних із біологією, географією, екологією, історією може бути різноманітною. Якщо повідомлення містить опис будь-якого явища або приклад фізичного явища в природі, його доцільно використовувати на уроці як ілюстрацію.

Наприклад, щодо теми «Прості механізми» можна навести такі приклади використання простих механізмів.

1. Вчені вважають, що перші колеса були створені в Шумері приблизно 5200 років тому. До винаходу колеса тяжкі предмети по суші переміщали за допомогою котків та важелів. 3 розвитком скотарства почали використовувати в'ючних тварин, з'явилися безколісні волокуші, що стали прообразом саней. Перші зображення колісного візка, що дійшли до нас, знайдені в Месопотамії; датуються вони 4 тисячоліттям до нашої ери.

2. Стародавні єгиптяни залишили по собі величні пам'ятки архітектури знамениті піраміди, гробниці фараонів. Європейці дізналися про ці грандіозні споруди після Єгипетського походу (1798-1801рр.) генерала Бонапарта (майбутнього імператора Франції): саме тоді було зроблено перші описи устрою гробниць. Доведено, що будівельна техніка давнини дозволяла зводити такі монументальні споруди. Блоки з вапняку вирубані у каменоломнях і на місці їх обробляли - обтісували та полірували. Виконували цю операцію мідними інструментами. Камінь обробляли так старанно, щоб у подальшому блоки щільно прилягали один до одного. Майстри домагалися дивовижних результатів - i через тисячоліття між гранями сусідніх плит не можна протягнути навіть нитку. Потім багатотонні блоки, використовуючи полозья-волокуші і прості важелі, вантажили на баржі і в період повені спеціально проритими каналами відправляли до місця будівництва. Втягували блоки на канаті мідними гаками. Головною таємницею пірамід є працьовитість та талант людини. Насправді висота піраміди фараона Хуфу (Хеопса) досягає 146.59 м, складена вона 3 величезних кам'яних блоків масою 2.5 т кожен.

При вивченні теми «Тертя» дуже цікавий приклад, який ілюструє переваги тертя кочення. 
3. Храм Артеміди в Ефесі (побудований близько 550 р. до нашої ери) був одним із найкрасивіших і найзнаменитіших творінь грецької архітектури i вважався третім дивом світу. Керівники будівництва Херсіфрон та Метаген при зведенні храму зіштовхнулися зі складною проблемою: як перевезти по рихлому грунту важкі колони та блоки 3 каменоломні до місця роботи? Вихід був знайдений: колону, особливим чином прикріплювали до дерев'яної рами, ніби перетворювали на кам'яну ковзанку. А перекочувати тяжкості набагато легше, ніж тягти. Для прямокутних блоків Метаген придумав інший спосіб: кожен блок, як вісь, вставляли у величезні дерев'яні колеса близько 4м в діаметрі і котили до місця будівництва.

Дуже цікавий приклад, що ілюструє застосування закону Паскаля, його можна запропонувати на уроках щодо теми: «Тиск газів».

4. Батьківщиною скла вважається багатий кварцовим піском Єгипет, де протягом багатьох століть виготовляли скляні намисто. Греки запозичили це ремесло у єгиптян, удосконалили його і почали робити скляні вази. Техніка видування скла за допомогою спеціальних труб і форм з'явилася в Сирії в 1 столітті до н.е. і швидко поширилася по всій Римській імперії. Скляні вироби кубки, келихи - стали набагато дешевшими і перетворилися на предмети масового попиту. Нові центри склоробства в Італії та римських провінціях. На території Іспанії, Франції, Німеччини.

Але ефективнішим $є$ вирішення фізичних завдань 3 увикористанням текстів, складених з урахуванням повідомлень з біології, хімії, географії, історії, екології.

Ось приклади деяких завдань, які пропонуються школярам під час уроків на тему «Швидкість. Поступовий рух».

1. Гриб райдуга (phallus), звичайний у наших краях, росте зі швидкістю 5 мм за хвилину і виростає до висоти 30 см. За який час гриб досягає вказаної висоти? (1 година)

2. Хоча рослина банан (Musa) досягає висоти 10 м і має ствол завтовшки до 1 м, воно є травою. Банан від початку розвитку до десятиметрової висоти 
зростає лише за 8-10 місяців. Листя банана росте зі швидкістю 0.1 мм за хвилину. Кожна рослина дає три врожаї на рік, що становить загалом 100 кг плодів. Визначте, на скільки сантиметрів збільшується лист банана на добу? (14,4 см)

3. Бамбуки - загальна назва для більш ніж 100 родів та 600 видів трав'янистих рослин. Їх особливістю є швидке зростання. Так, бамбуки В'єтнаму ростуть зі швидкістю 2 м на добу. Бамбук, що відноситься до сімейства злакових, у себе на батьківщині може досягати висоти 50 м і мати стебло діаметром до 40 см. На скільки метрів змінюється довжина бамбука за тиждень? (на 14 м)

Можна на цю тему запропонувати учням творче завдання. Наприклад, пропонується таблиця, в якій вказані швидкості руху живої природи. Школярам пропонується скласти завдання за цими даними.

Ось такі завдання складають школярі.

1. Гепарди полюють поодинці. Вони біжать за здобиччю зі швидкістю до 30 м/с, але досить швидко втомлюються. Якщо протягом хвилини вони не наздоганяють здобич, то припиняють гонитву. Антилопа знаходиться на відстані 100 м від гепарду і біжить зі швидкістю 72 км/год. Чи наздожене іiї гепард?

Відповідь: Якщо рухатиметься з максимальною швидкістю, то наздожене через $10 \mathrm{c}$.

2. Африканські страуси, нанду та ему - це великі безкрилі птахи. Вони досить швидко бігають, щоби втекти від небагатьох хижаків, які ризикують нападати на них. Страуси біжать зі швидкістю 80 км/год. Всі вони неяскраво пофарбовані, крім чорно-білого африканського страуса, який є найбільшим птахом у світі. За який час африканський страус подолав би стометрівку?

Відповідь: Приблизно за 4,5 с.

Дуже цікаво можна робити уроки «Рішення задач» 3 використанням цікавих повідомлень. Так учням пропонується цікавий факт, а вони мають скласти по ньому задачу чи питання. А потім запропонувати відповісти на нього своїм товаришам. Наприклад, деякі повідомлення на тему «Маса. Щільність».

Сейшельська віялова пальма дає горіхи масою до 25 кг та діаметром до 0,5 м. Вперше такий горіх потрапив до Європи наприкінці XVI століття. Європейці 
вважали його талісманом, який оберігає від нещасть, і високо цінували: за один «Мальдівський горіх» можна було отримати цілий корабель, завантажений товарами. Імператор «Священної Римської імперії» Рудольф II (1552-1612) заплатив за кубок з горіха сейшельської пальми стільки золота, скільки в нього вмістилося - 100 кг.

Ось такі задачі були складені на уроці цього уривку:

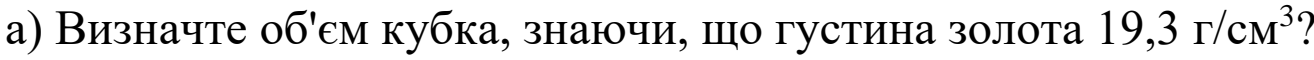

б) Вважаючи, що сейшельський горіх має форму кулі, визначте іiі середню густину. 3 якою речовиною може зрівнятися ця густина?

Цератонія із сімейства цезальпінієвих дає однакове насіння, масою завжди рівно 0,2 г. Таким насінням як гирєю із давнини користувалися ювеліри. Цей захід маси назвали каратом.

Ось які завдання було складено за цим фактом.

а) Які одиниці маси ви знаєте? Скільки карат за 100 г?

б) Алмаз масою 20 карат має об'єм 0,63 см. Визначте середню густину цього каменю? Вас нічого не дивує?

в) Скільки насіння цератонії потрібно взяти, щоб урівноважити брусочок срібла розмірами $1 * 2 * 2 \mathrm{~cm}^{3}$ ? Щільність срібла 10500 кг $/ \mathrm{M}^{3}$.

Такі завдання дозволяють учням застосувати свої знання практично, розвивають мислення і логіку учнів. Допомагають краще зрозуміти фізику. Усі учні, які активно беруть участь у цій роботі, заохочуються.

За запропонованою методикою можна проводити не лише окремі уроки, а й позакласні заняття та заходи. Такі заняття позитивно впливають на засвоєння основного шкільного курсу фізики, і навіть сприяють розвитку умінь вирішувати задачі творчого характеру. Вирішення таких задач спонукають учнів читати більше, самим знаходити цікаві факти, а потім використовувати їх на уроці або на позакласному занятті. Це розвиває в учнів мислення, увагу, спостережливість.

Слід зазначити, що з практичного досвіду, завдання, пов'язані з біологією, хімією, географією чи екологією допоможуть вчителю урізноманітнити уроки та 
заняття з фізики, залучити учнів до активної творчої діяльності, розвинути у школярів любов до рідної природи.

Важливим завданням під час уроків 3 формування знань 3 фізики стає ознайомлення школярів 3 недостатнім розвитком сучасної науки, створення уявлень учнів сучасної картини світу.

На сьогодняшній день існує багато посібників для вчителів 3 викладання дисциплін природничого циклу, в яких представлені завдання та короткі довідки, практичні та дослідницькі роботи з фізики з елементами біології, географії, екології, які можуть використовуватися вчителем на уроках з формування знань з фізики та позаурочній діяльності, а також учнями при підготовці до уроків, при написанні доповіді, для саморозвитку та самопідготовки, для розширення кругозору, а також для творчої роботи. На основі коротких довідок, представлених у таких посібниках, школярі привчаються ілюструвати закони фізики прикладами суміжних предметів.

Мета посібників запровадити в урок елементи цікавості та пізнавальні моменти, підвищити інтерес до вивчення фізики та збільшити кругозір школярів, залучити до пошуку та спонукати учнів до читання додаткової літератури. Матеріали, що представлені у посібниках, можуть бути використані на різних етапах уроку: під час перевірки домашнього завдання, при дачі нового матеріалу, при закріпленні нового матеріалу; як короткі повідомлення на тему, цікавих завдань, матеріалу, що розвиває характер, для складання питань і завдань самими школярами.

3 усього вище сказаного можна дійти висновку, що необхідність звернення до інтегрованого навчання викликана низкою об'єктивних причин, які дедалі частіше виявляються у середній школі.

Однією з найважливіших проблем є помітне зниження інтересу учнів до предметів природничо-наукового циклу, що обумовлено об'єктивною складністю таких наук як фізика, хімія і біологія. До того ж, викликає незадоволеність недостатня продуманість та розробленість діючих програм та підручників для загальноосвітніх шкіл. 
Сама специфіка цих наук на їх сучасному рівні спонукає до комплексного підходу у навчанні школярів цим предметам, тобто логіка даних наук веде до їх об'єднання - інтеграції.

Наступною проблемою, яку можна вирішити у процесі інтегрованого навчання, є неузгодженість, роз'єднаність етапів формування в учнів загальних понять фізики, хімії та біології; вироблення у них узагальнених умінь і навичок. Практика показує, що нерідко те саме поняття у межах кожного конкретного предмета визначається по-різному - така багатозначність наукових термінів ускладнює сприйняття навчального матеріалу. Неузгодженість пропонованих програм призводить до того, що та сама тема з різних предметів вивчається у час. Ці протиріччя легко знімаються в інтегрованому навчанні, яке вирішує ще одну проблему - економії навчального часу.

Необхідно також відзначити ще один важливий момент: інтегроване навчання покликане відобразити інтеграцію наукового знання, яка об'єктивно відбувається у суспільстві. Однак, не висвітлювати міжнаукові зв'язки або показувати їх поверхово було б великим недоліком сучасної школи. Інтегроване навчання дозволяє найбільш ефективно показати міждисциплінарні зв'язки та природничо метод дослідження, що використовується на стику наук. 